УДК [378.091.12:36-051]:004:005.336.2

Павлишина Наталія Борисівна

старший викладач кафедри педагогіки вищої школи

ПВНЗ «Академія рекреаційних технологій і права», м. Луцьк, Україна

pavlyshyna@ukr.net

\title{
АНАЛІЗ СУЧАСНОГО СТАНУ ЗАСТОСУВАННЯ ІНФОРМАЦИЙНИХ ТЕХНОЛОГІЙ У ПРОФЕСІЙНІЙ ПІДГОТОВЦІ МАЙБУТНІХ СОЦІАЛЬНИХ ПРАЦІВНИКІВ
}

\begin{abstract}
Анотація. У статті здійснено дослідження стану впровадження інформаційних технологій у підготовку майбутніх соціальних працівників до професійної діяльності у закладах соціального обслуговування людей похилого віку. Виявлено рівень задоволеності науковопедагогічних працівників якістю електронного науково-методичного забезпечення дисциплін, спрямованих на формування готовності майбутніх соціальних працівників до професійної діяльності у закладах соціального обслуговування людей похилого віку. 3'ясовано, яка частка викладачів спрямовують зусилля на розробку власного електронного науково-методичного забезпечення i використовують мультимедійні засоби навчання, інформаційні ресурси мережі Інтернет, електронне тестування з навчальних дисциплін й Інтернет-платформу організації дистанційного навчання Moodle у професійній підготовці майбутніх соціальних працівників.
\end{abstract}

Ключові слова: соціальний працівник; підготовка; інформаційні технології; заклади соціального обслуговування; люди похилого віку.

\section{1. ВСТУП}

Постановка проблеми. Використання інформаційних технологій у підготовці фахівців вищих навчальних закладів $є$ однією 3 вагомих вимог державних освітніх стандартів вищої професійної освіти. Саме залучення інформаційних технологій у навчальний процес підготовки майбутніх соціальних працівників сприяє підвищенню якості засвоєння студентами необхідних теоретичних і практичних знань, допомагає самостійно опановувати нову інформацію на базі сучасних Інтернет технологій.

У Законі України «Про основні засади розвитку інформаційного суспільства в Україні на 2007-2015 роки» (2007) серед основних стратегічних цілей розвитку вітчизняного інформаційного суспільства визначено такі: забезпечити комп’ютерну й інформаційну грамотність населення, насамперед шляхом створення системи освіти, орієнтованої на використання новітніх інформаційно-комунікаційних технологій у формуванні всебічно розвиненої особистості; створити системи дистанційного навчання і забезпечити на їх основі ефективне впровадження і використання інформаційнокомунікаційних технологій на всіх освітніх рівнях усіх форм навчання [2].

Для вдосконалення підготовки фахівців, які поєднують високу професійну компетентність, мобільність, соціальну активність, гуманізм та інші якості, що допоможуть успішно співіснувати фахівцю соціальної роботи в інформаційному суспільстві, потрібні певна оптимізація й актуалізація впровадження інформаційних технологій у навчальний процес вищих навчальних закладів.

Вважаємо, що однією 3 умов формування готовності майбутніх соціальних працівників до професійної діяльності у закладах соціального обслуговування людей похилого віку є використання інформаційних засобів навчання для набуття професійної компетентності щодо соціальної роботи 3 людьми похилого віку, яка дозволяє спрямувати студентів на саморозвиток і самоосвітню діяльність. Проте, у вищих 
навчальних закладах не приділена достатня увага проблемі використання інформаційних технологій у підготовці майбутніх соціальних працівників до здійснення професійної діяльності у закладах соціального обслуговування людей похилого віку.

Аналіз останніх досліджень i публікацій. Проблемами впровадження інформаційних технологій у професійну підготовку фахівців займалися такі вчені, як В. Безпалько, В. Биков, В. Глушков, М. Жалдак, Ю. Машбиць, Н. Морзе та ін.

Зокрема, актуальність використання інформаційних технологій у вищій освіті, на думку Л. В. Оршанського, визначається такими факторами: винятково широкими можливостями в індивідуалізації освіти; підвищенням мотивації суб' єктів навчання під час їх використання і посиленням емоційного фону освітнього процесу; розмаїттям умов і механізмів для активної самостійної діяльності; забезпеченням широкої зони контактів, можливістю спілкування через Інтернет з будь-якою людиною, незалежно від іiі просторового розташування і різниці часових поясів; можливістю комплексного впливу на різні органи чуття; високою наочністю подання навчального матеріалу; зростаючими інтерактивними можливостями IT-технологій; доступністю IT-технологій у будь-який час, зручний для суб'єкта навчання; легкістю і звичністю організації ігрових форм навчання [4].

Питання використання інформаційно-комунікаційних технологій у фаховій підготовці соціальних працівників розкриті у працях Л. А. Дітковської [1].

Мета статті. 3 огляду на зазначене, метою статті $є$ дослідження окремих аспектів застосування інформаційних технологій у професійній підготовці майбутніх соціальних працівників.

\section{2. ТЕОРЕТИЧНІ ОСНОВИ ДОСЛІДЖЕННЯ}

Використання таких перспективних інформаційних технологій як мультимедія, Інтернет технології, дистанційне навчання, сприяє підвищенню інформаційної компетентності майбутніх соціальних працівників. У результаті, соціальний працівник вмітиме обирати і використовувати в процесі професійної діяльності такі інформаційні методи, які сприятимуть досягненню позитивного результату у здійсненні соціальної роботи з клієнтами геронтологічної групи.

Інформаційне забезпечення процесу формування готовності майбутніх соціальних працівників до здійснення професійної діяльності у закладах соціального обслуговування людей похилого віку полягає у використанні сучасних комп'ютерних технологій. Зокрема, мультимедійні лекції сприяють підвищенню інтерактивного діалогу між лектором і аудиторією, що, у свою чергу, впливає на розвиток у студентів здатності до здійснення аналізу й узагальнення отриманої інформації. Технологія мультимедія також сприяє активізації пізнавальної діяльності студентів.

Інформаційно-комп'ютерне забезпечення навчальних дисциплін включає створення електронних навчально-методичних комплексів і розміщення їх на Інтернетплатформах організації дистанційного навчання.

Інтерактивне спілкування під час аудиторних занять за допомогою смартфонів $\mathrm{i}$ ноутбуків сприяє активізації процесу взаємодії аудиторії. Студенти мають можливість отримувати додаткову інформацію в Інтернеті, брати участь у спеціальних Інтернетопитуваннях, проходити різноманітні тестування онлайн.

\section{3. МЕТОДИКА ДОСЛІДЖЕННЯ}

3 метою дослідження стану впровадження інформаційних технологій у підготовку майбутніх соціальних працівників до професійної діяльності у закладах соціального 
обслуговування людей похилого віку було проведено анкетування викладачів вищих навчальних закладів, у яких здійснюється підготовка фахівців соціальної роботи. В анкетуванні взяло участь 86 науково-педагогічних працівників, зокрема 12 науковопедагогічних працівників Донбаського державного педагогічного університету, 11 викладачів Запорізького національного університету, 10 викладачів Національного університету «Львівська політехніка», 16 викладачів Східноєвропейського національного університету імені Лесі Українки, 18 викладачів Тернопільського національного педагогічного університету імені Володимира Гнатюка, 10 Відкритого міжнародного університету розвитку людини «Україна», 9 - Луцького інституту розвитку людини Університету «Україна».

\section{4. РЕЗУЛЬТАТИ ДОСЛІДЖЕННЯ}

Питання анкети мали за мету дізнатися, чи задовільняє викладачів якість електронного науково-методичного забезпечення дисциплін, спрямованих на формування готовності майбутніх соціальних працівників до професійної діяльності у закладах соціального обслуговування людей похилого віку. Зокрема, серед 86 опитаних науково-педагогічних працівників, лише $27,9 \%$ респондентів задоволені якістю електронного науково-методичного забезпечення таких дисциплін; 40,7\% викладачів не задоволені; 31,4\% опитаним важко відповісти (рис. 1).

Наскільки науково-педагогічні працівники спрямовують свої зусилля на розробку власного електронного науково-методичного забезпечення, необхідного для формування готовності майбутніх соціальних працівників до професійної діяльності у закладах соціального обслуговування людей похилого віку, виявило наступне запитання анкети. Так, 45,4\% респондентів спрямовують зусилля на розробку і видання такого науково-методичного забезпечення; $36 \%$ опитаних зазначили, що не спрямовують; 18,6\% викладачам важко відповісти (рис. 1).

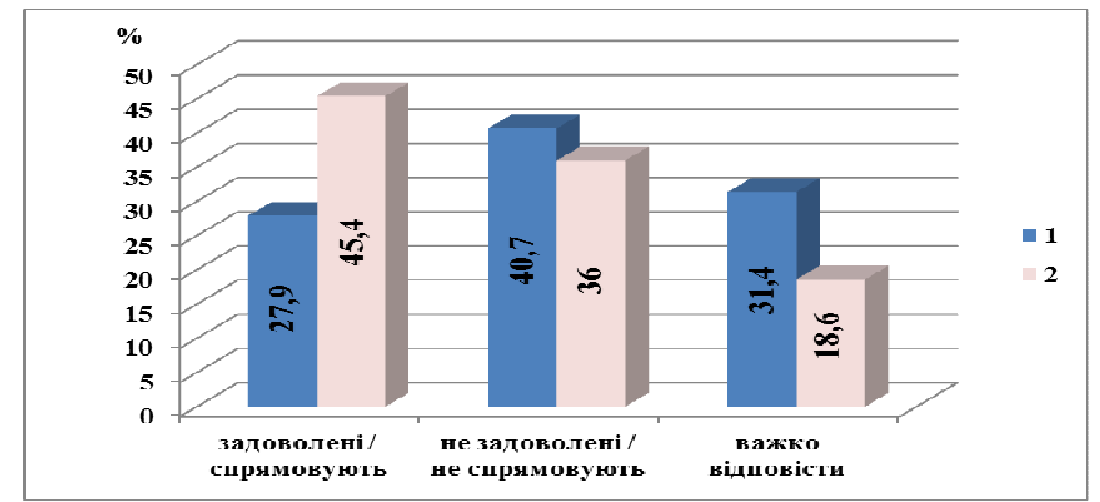

Розподіл відповідей студентів щодо задоволення якістю електронного науково-методичного забезпечення, необхідного для формування готовності майбутніх соціальних працівників до професійної діяльності у закладах соціального обслуговування людей

Розподіл відповідей студентів щодо спрямування своїх зусиль на розробку власного електронного науковометодичного забезпечення, необхідного для формування готовності майбутніх соціальних працівників до професійної діяльності у закладах соціального обслуговування людей похилого віку

Рис. 1. Розподіл відповідей викладачів, опитаних про стан електронного науковометодичного забезпечення, необхідного для формування готовності майбутніх сочіальних працівників до професійної діяльності у закладах сочіального обслуговування людей похилого віку (\%) 
Отже, 27,9\% викладачів задоволені якістю електронного науково-методичного забезпечення, необхідного для формування готовності майбутніх соціальних працівників до професійної діяльності у закладах соціального обслуговування людей; у той же час $45,4 \%$ опитаних спрямовують зусилля на розробку і видання такого науково-методичного забезпечення. Проте 40,7\% науково-педагогічних працівники не задоволені якістю електронного науково-методичного забезпечення таких дисциплін, а $36 \%$ респондентів не спрямовують зусилля на розробку і видання такого науковометодичного забезпечення. Тому потрібно більше зусиль спрямовувати на розробку власного електронного методичного забезпечення дисциплін.

Аналіз відповідей викладачів про те, чи проводять вони електронне тестування 3 навчальних дисциплін, спрямованих на формування готовності майбутніх соціальних працівників до професійної діяльності у закладах соціального обслуговування людей похилого віку, виявив таке: $16,3 \%$ респондентів проводять таке тестування; 31,4\% опитаних - рідко проводять; 46,5\% науково-педагогічних працівників - не проводять; 5,8\% викладачам важко відповісти (рис. 2).

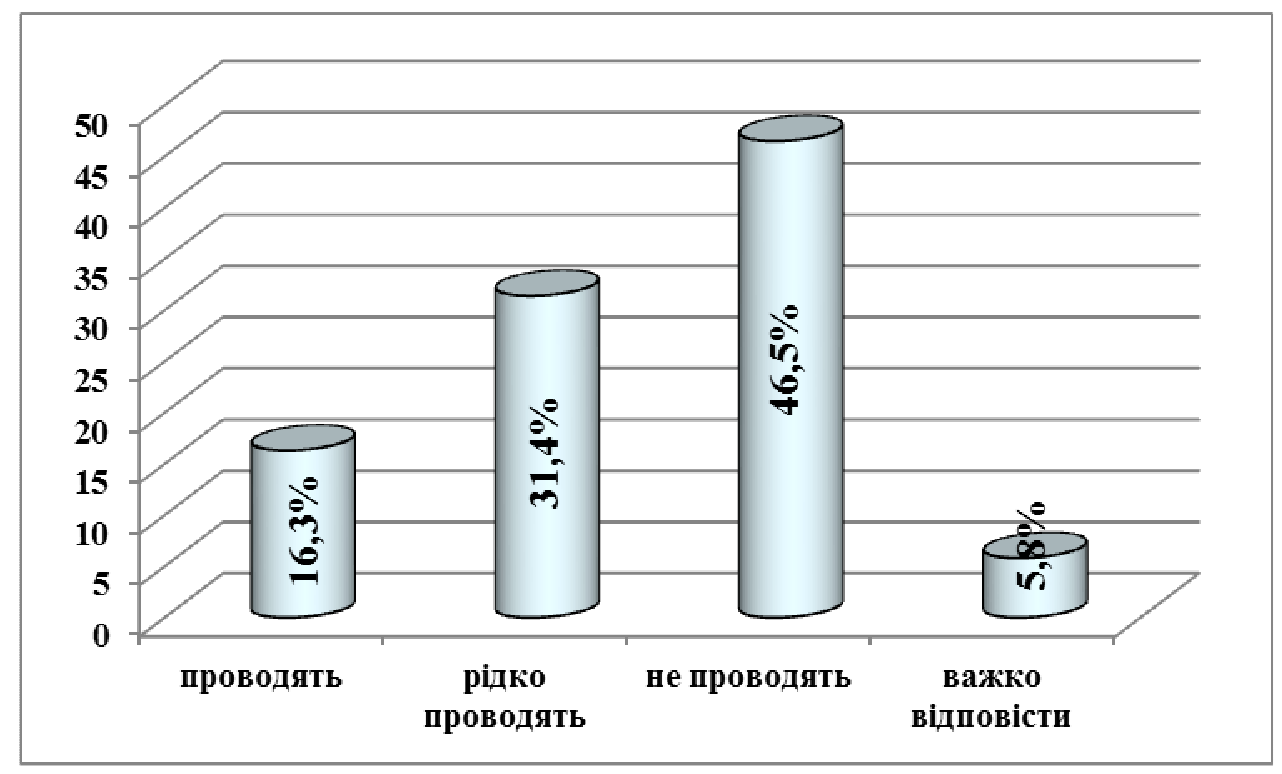

Рис. 2. Розподіл відповідей викладачів, опитаних про проведення електронного тестування з навчальних дисииплін, спрямованих на формування готовності майбутніх соціальних працівників до професійної діяльності у закладах соціального обслуговування людей похилого віку (\%)

Щодо використання науково-педагогічними працівниками мультимедійних засобів навчання й інформаційних ресурсів мережі Інтернет з метою підвищення якості підготовки майбутніх соціальних працівників до професійної діяльності у закладах соціального обслуговування людей похилого віку, то результати анкетування свідчать про те, що 52,3\% респондентів використовують такі засоби і ресурси; 24,4\% опитаних — рідко використовують; 17,4\% викладачів — не використовують; 5,8\% науковопедагогічні працівникам важко відповісти (рис. 3). 


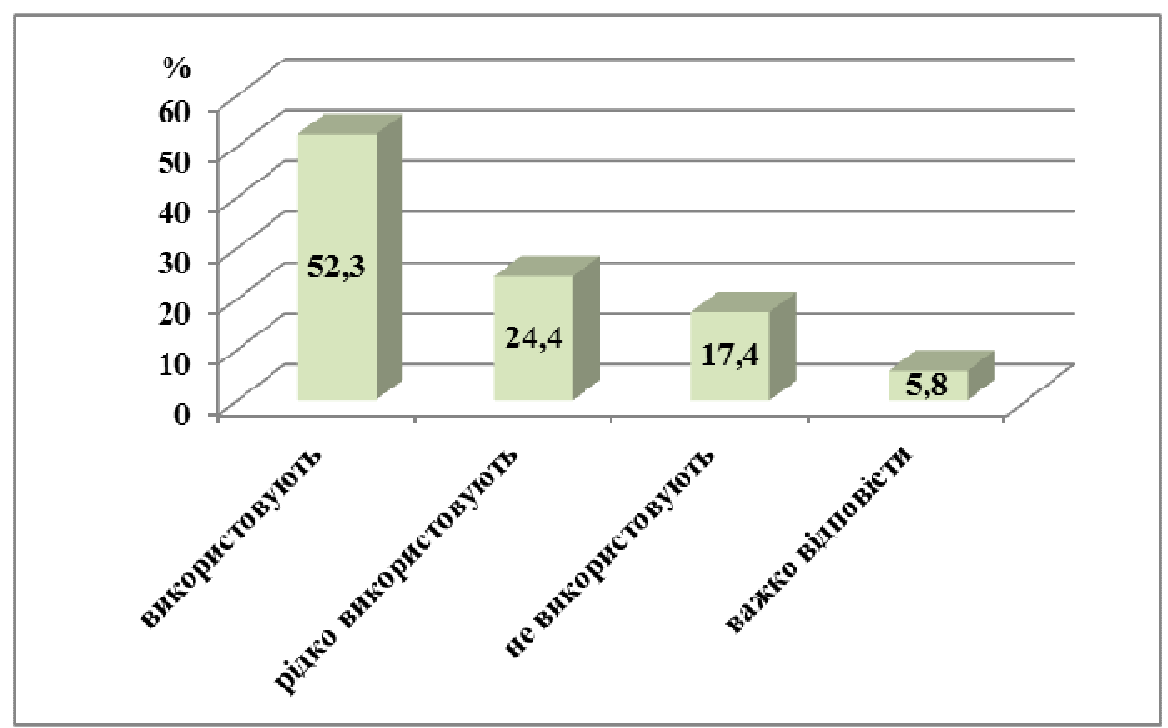

Рис. 3. Розподіл відповідей викладачів, опитаних про використання мультимедійних засобів навчання й інформаційних ресурсів мережі Інтернет з метою підвищення якості підготовки майбутніх соиіальних праџівників до професійної діяльності у закладах соиіального обслуговування людей похилого віку (\%)

Отже, майже половина викладачів використовує мультимедійні засоби навчання й інформаційні ресурси мережі Інтернет 3 метою підвищення якості підготовки майбутніх соціальних працівників до професійної діяльності у закладах соціального обслуговування людей похилого віку. У той же час, лише $16,3 \%$ респондентів використовують електронне тестування з навчальних дисциплін, яке, на нашу думку, дає можливість швидко й ефективно тестувати знання студентів.

Цікаво було дізнатися, чи використовують науково-педагогічні працівники у професійній підготовці майбутніх соціальних працівників до професійної діяльності у закладах соціального обслуговування людей похилого віку, Інтернет-платформу організації дистанційного навчання Moodle. Відповіді опитаних викладачів дозволять констатувати, що лише 21,2\% респондентів використовують таку Інтернет-платформу; значна частина опитаних $(63,7 \%)$ - не використовують; $15,1 \%$ - важко відповісти (рис. 4).

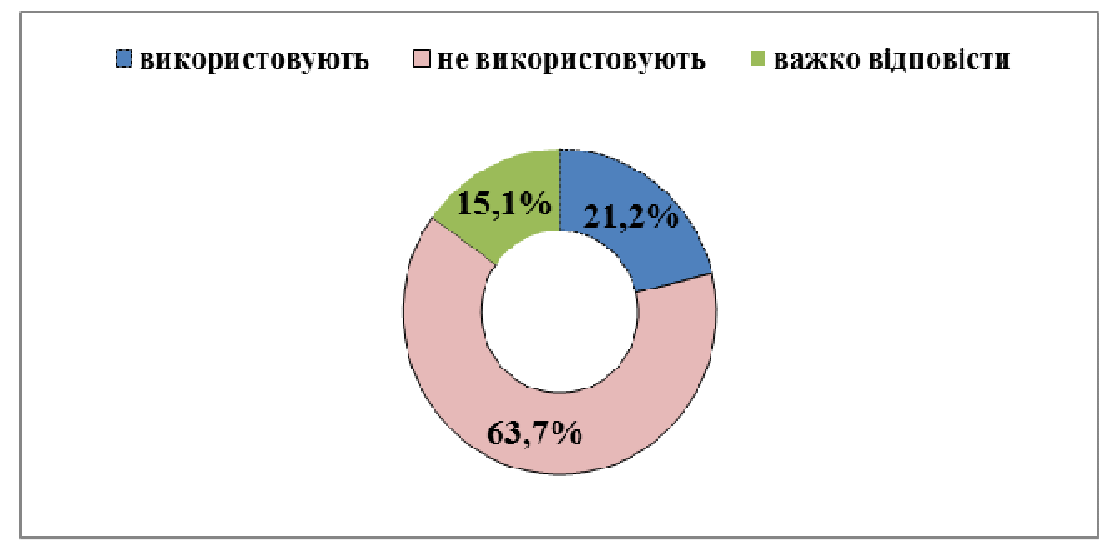

Рис. 4. Розподіл відповідей викладачів, опитаних про використання Інтернетплатформи організачї дистаниійного навчання Mооdle в прочесі професійної підготовки майбутніх сочіальних працівників, здатних до професійної діяльності у закладах сочіального обслуговування людей похилого віку (\%) 


\title{
5. ВИСНОВКИ ТА ПЕРСПЕКТИВИ ПОДАЛЬШИХ ДОСЛІДЖЕНЬ
}

1. Опитування науково-педагогічних працівників щодо стану впровадження в освітній процес таких перспективних інформаційних технологій як електронне науково-методичне забезпечення дисциплін, електронне тестування, мультимедійні засоби навчання, інформаційні ресурси мережі Інтернет та Інтернет-платформи організації дистанційного навчання Moodle, свідчить про недостатнє їх використання у підготовці майбутніх соціальних працівників до здійснення соціального обслуговування людей похилого віку.

2. Лише 27,9\% викладачів задоволені якістю електронного науково-методичного забезпечення, необхідного для формування готовності майбутніх соціальних працівників до професійної діяльності у закладах соціального обслуговування людей; у той же час $45,4 \%$ опитаних спрямовують зусилля на розробку і видання такого науково-методичного забезпечення. Проте, 40,7\% науково-педагогічних працівники не задоволені якістю електронного науково-методичного забезпечення таких дисциплін, а $36 \%$ респондентів не спрямовують зусилля на розробку і видання такого науковометодичного забезпечення. Тому потрібно більше зусиль спрямовувати на розробку власного електронного методичного забезпечення дисциплін.

3. Майже половина викладачів використовує мультимедійні засоби навчання й інформаційні ресурси мережі Інтернет 3 метою підвищення якості підготовки майбутніх соціальних працівників до професійної діяльності у закладах соціального обслуговування людей похилого віку. У той же час, лише $16,3 \%$ респондентів використовують електронне тестування з навчальних дисциплін, яке, на нашу думку, дає можливість швидко й ефективно тестувати знання студентів.

3 огляду на це, перспективи подальших досліджень полягають у науковому обгрунтуванні впровадження інформаційних технологій як однієї з педагогічних умов формування готовності майбутніх соціальних працівників до професійної діяльності у закладах соціального обслуговування людей похилого віку.

\section{СПИСОК ВИКОРИСТАНИХ ДЖЕРЕЛ}

1. Дітковська Л. А. Організаційно-педагогічні умови формування ікт-компетентності майбутніх соціальних працівників [Електронний ресурс] / Л. А. Дітковська // Вісник Луганського національного університету імені Тараса Шевченка. Педагогічні науки . - 2013. - № 21. - С. 3646. - Режим доступу : http://nbuv.gov.ua/j-pdf/vlup_2013_21_8.pdf.

2. Закон України «Про основні засади розвитку інформаційного суспільства в Україні на 2007-2015 роки» [Електронний ресурс]. - Режим доступу : http://zakon.rada.gov.ua/cgibin/laws/main.cgi?nreg=537-16.

3. Закон України «Про соціальні послуги» від 19.06.2003 №966-IV // Голос України. — 2003. - 22 лип.

4. Оршанський Л. В. Креативне інформаційно-освітнє середовище як чинник саморозвитку особистості [Електронний ресурс] / Л. В. Оршанський. - Режим доступу http://www.nbuv.gov.ua/portal/soc_gum/Sitimn/2010_23/Kreatuvne_informaziino_osv_seredov.pdf.

Матеріал надійшов до редакиії 01.04.2015 p.

\author{
АНАЛИЗ СОВРЕМЕННОГО СОСТОЯНИЯ ПРИМЕНЕНИЯ \\ ИНФОРМАЦИОННЫХ ТЕХНОЛОГИЙ В ПРОФЕССИОНАЛЬНОЙ \\ ПОДГОТОВКЕ БУДУЩИХ СОЦИАЛЬНЫХ РАБОТНИКОВ
}




\title{
Павлишина Наталия Борисовна
}

старший преподаватель кафедры педагогики высшей школы ЧВУЗ «Академия рекреационных технологий и права», г. Луцк, Украина pavlyshyna@ukr.net

\begin{abstract}
Аннотация. В статье проведено исследование состояния внедрения информационных технологий в подготовку будущих социальных работников к профессиональной деятельности в учреждениях социального обслуживания людей преклонного возраста. Выявлен уровень удовлетворенности научно-педагогических работников качеством электронного научно-методического обеспечения дисциплин, направленных на формирование готовности будущих социальных работников к профессиональной деятельности в учреждениях социального обслуживания пожилых людей. Выяснено, какая часть преподавателей направляют усилия на разработку собственного электронного научнометодического обеспечения и используют мультимедийные средства обучения, информационные ресурсы сети Интернет, электронное тестирование по учебным дисциплинам и Интернет-платформу организации дистанционного обучения Moodle в профессиональной подготовке будущих социальных работников.
\end{abstract}

Ключевые слова: социальный работник; подготовка; учреждение социального обслуживания; люди преклонного возраста; информационные технологии.

\section{ANALYSIS OF CURRENT STATE OF INFORMATION TECHNOLOGIES USAGE OF FUTURE SOCIAL WORKERS' TRAINING}

\author{
Nataliia B. Pavlyshyna \\ Senior lecturer of Higher School Pedagogics Department \\ Private Higher Educational Establishment «Academy of Recreational Technologies and Law», Lutsk, Ukraine \\ pavlyshyna@ukr.net
}

\begin{abstract}
Absract. In the article the state of information technologies implementation in the training of future social workers for professional work in institutions of social services for the elderly has been carried out. It has been stated that teaching staff is satisfied with the quality of electronic scientific methods of discipline aimed at training of the future social workers for professional work in institutions of social services for the elderly. It has been found that an amount of respondents direct efforts to develop their own scientific and methodological support, use multimedia learning and information resources on the Internet, electronic testing disciplines and Moodle online distance learning platform.
\end{abstract}

Keywords: social worker; training; institutions of social services; the elderly; information technologies.

\section{REFERENCES (TRANSLATED AND TRANSLITERATED)}

1. Ditkovska L. A. Organizational and Pedagogical Conditions of Social Workers Competence [online] / L. A. Ditkovska // Visnyk Luhanskoho natsionalnoho universytetu imeni Tarasa Shevchenka. Pedahohichni nauky. — 2013. — № 21. - S. 36-46. - Available from : http://nbuv.gov.ua/j-pdf/vlup_2013_21_8.pdf (in Ukrainian).

2. The Law of Ukraine «On the Fundamentals of Information Society in Ukraine in 2007-2015» [online]. Available from : http://zakon.rada.gov.ua/cgi-bin/laws/main.cgi?nreg=537-16 (in Ukrainian).

3. The Law of Ukraine „On Social Services” from 19.06.2003 №966-IV // Holos Ukrainy. — 2003. - 22 lyp (in Ukrainian).

4. Orshanskyi L. V. Creative Informational and Educational Environment as a Factor of Self-identity [online] / L. V. Orshanskyi. - Available from :

http://www.nbuv.gov.ua/portal/soc_gum/Sitimn/2010_23/ Kreatuvne_informaziino_osv_seredov.pdf (in Ukrainian). 